\title{
Differential community effects on perception and use of urban greenspaces
}

\author{
Alex Y. Lo ${ }^{1}$ and C.Y. Jim ${ }^{2, *}$ \\ ${ }^{1}$ Research School of Social Sciences, The Australian National University, Canberra, ACT 0200, \\ Australia \\ ${ }^{2}$ Department of Geography, University of Hong Kong, Pokfulam Road, Hong Kong
}

\begin{abstract}
The social profiles of residential communities exert differential effects on expectations and demands on urban greenspaces. We studied the diversity of public perception towards urban greenspaces in compact urban Hong Kong. Random household samples were selected from four dominant residential communities: old-core public housing (OP), old-core residential (OR), suburban residential (SR), and new-town public housing (NP). They denote gradations in income, housing quality, physical and social milieu, and development age. Face-to-face interviews were conducted using a structured questionnaire. Residents’ attitude, visiting pattern, greenspace preference, and assessment of neighborhood quality were investigated. SR presented distinctive results in comparison with others. The moderate differences between the remaining three communities were mainly linked to local traits in park environs. OP more emphasized the function of communal places for neighborly interactions associated with better social relationship of an older population. Parks in OR were the more frequently visited, even though its residents were sensitive to the negative impacts of urban greenspaces, which was related to urban blight in the environs. SR respondents highly appreciated greenspaces as pleasant settings for family activities and aesthetic enjoyment. NP residents were less frequent visitors despite generous park provision, due to the youthful population, weak social cohesion, and limited integration of new migrants. Community quality factors such as neighborhood relationship and urban density influenced the perception. Social qualities were more important than the physical aspects of parks in influencing visitorship. The findings suggest future research to deepen understanding of public perception towards urban greenspaces to inform park design.
\end{abstract}

Keywords: Urban greenspace; public perception; Community effect; Social function; Outdoor recreation; Compact city

(accepted for publication in Cities on 2 July 2010) 


\section{Differential community effects on perception and use of urban greenspaces}

\section{Introduction}

The perception of nature denotes a sentimental attachment to the surroundings (Tuan, 1974). Human environmental attitude manifests as a subjective expression of the linkages in the nature-society complex. Environmental decisions could benefit from a multiple-factor perspective. The broadening scope of relevant research reflects the trend towards a holistic assessment of the environment. It has been proposed that environmental behaviors are a function of past experience and memory, value and beliefs, and local culture and history (Burgess et al., 1988; Coles and Bussey, 2000; Noël et al., 2000; Bhagwat, 2009; Drenthen, 2009; Hung, 2010).

Urban greenspaces (UGS) consist of vegetated and open spaces within city limits, commonly in the form of public parks. Most urban park visitors are derived from a local catchment area, often within short walking distance (Hayward and Weitzer, 1983; Walker and Duffield, 1983). The physical and social milieu of the users could influence their perception of local UGS. As an integral part of urban ecosystems, they provide diverse ecological services and social and recreational benefits. The physical structure and activities around UGS vary by neighborhoods. Community diversities create varied backdrops to UGS to engender spatial variations in the perception and use of UGS. In this study, the term community refers to a neighborhood of residents with similar socio-economic background and the associated interpersonal relationship and networking. Community quality refers to the environmental and social conditions with implications on the quality of life within and in the environs of a community.

Few studies focused on the environs experienced by individuals as reflected by neighborhood conditions (Palmer, 1984; Grove et al., 2006; Kearney, 2006). The current practice of quantitative survey has excessively focused on socioeconomic variables of park visitors and intrinsic park features per se (Grove et al., 2006). Non-park extrinsic elements in the environs, such as actual and perceived development density, local public security condition and neighborhood relationship, are rarely and systematically tested with the help of field survey data. The current practice lacks a broader cultural context. Park boundary is usually defined narrowly as physical, an approach that could fail to capture the intimate cultural embedment of UGS into the urban milieu. A broader definition and understanding of the wider park environment at the community level is needed. This study attempts to fill the void by exploring the effect of the non-park extrinsic elements, thereafter called 'community quality attributes'.

Understanding community needs and expectations of UGS has important policy and cost-effectiveness implications (Dooling et al., 2006). The provision of this essential public service involves issues of distributional justice and utilization rate in different parts of a city (Erkip, 1997; Benton, 2008; Lo and Jim, 2010). Assessing user feedbacks, attitude and 
behavior could help to design parks that are socially relevant and inclusive (Young and Flowers, 1982; Jay and Schraml, 2009). Users are not passive participants; instead, they enliven parks which in turn activate the community (Müller-Perband, 1979). Parks that fail to meet visitor needs require restoration and regeneration to encompass humanistic dimensions (Lambert, 2002). The social and psychological benefits of parks are increasingly supplementing environmental and ecological functions in the quest for sustainable cities and improved urban life (Burgess et al., 1988; Gobster, 1998). Park planning could seamlessly integrate with management to satisfy these enlightened objectives (Barber, 2002).

The paper involves a case study of Hong Kong. Greenspace planning in Hong Kong was based on managerial perspectives and not primarily driven by community needs. Recent participatory initiatives may benefit from a scientific investigation of public views. Moreover, the compact urban milieu has pooled diverse user groups into a small area. Understanding differential community needs is particularly important to effective planning., Also, the proximity of urban parks to other land uses may result in non-park extrinsic factors having greater impact on perception of parks.

We sought to understand people's attitude and perception towards UGS and visiting patterns. Including a diverse community profile is instrumental to understanding the role of community perception. We evaluated the nature and degree of variations by comparing the communities. We identified the underlying factors of public preference and visiting pattern by statistically testing key community attributes. The relevant research questions are: to what extent in which the perceptual variations depend on community quality attributes, and what is the relative contribution of individual socioeconomic variables. Specific hypotheses are explained in the context of individual study areas.

\section{Study areas}

The rugged topography of Hong Kong with little developable land has created an exceptionally compact city characterized by high population and building densities. The population of 7 million with an average density of 6,330 persons/ $\mathrm{km} 2$ is concentrated in about $200 \mathrm{~km} 2$ of urbanized land which occupies only $20 \%$ of the territory (Jim, 2000).

To investigate community variations in terms of residents' perception, stratified sampling of four representative residential communities, each contributing two to three sites, was adopted (Figure 1). Key social attributes were used as selection criteria, including features common and unique to individual communities (Table 1). An extensive review of government statistics, literature and official and non-government reports, supported by site inspections and our experience as locals, helped to identify these attributes.

The Old-core Public Housing (OP) consists of three old estates established 35-50 years ago in the old city core (Figure 1). Many of the low-income working-class residents have lived there for several decades to become elderly. Having collectively witnessed the socio-economic changes and shared the tribulations and unsatisfactory living environment, the residents have 
developed a strong bond and sense of neighborhood (Leung, 1999). Public parks around the estates are popular sojourns and extended homes due to the grave shortage of indoor domestic space. The huge public housing sector established by the government accommodates about $45 \%$ of the population of seven million in Hong Kong.

Homogeneity within the sampled communities is mainly reflected by the demographic traits. OP and NP are more homogeneous because they are government-subsidized public rental housing. Residents are selected stringently by the authority which applies strict regulations to applications mainly based on income level. Many applications from new immigrants and younger families are assigned to new towns, whereas OP is composed of mainly long-standing residents with few new comers. These low-income groups normally cannot afford to live in SR which is tailored for middle-income people. The well-educated and higher-income residents in SR are thus selected principally by affordability. OR residents may come from a mixed background, which reflects the local demography of an old city core not deliberately planned but has grown organically over the years.

The overcrowded household environment might act as a catalyst to push or decant residents into the public domain for leisure activities (Lee and Yip, 2006). The literal extension of the living room into neighborhood greenspaces has effectively increased the chance and duration for social exchanges. Due to land constraint, the size and number of public parks are limited. This limitation forces spatial clustering of residents regardless of the quantity and quality of greenery and facilities, with more frequent and close interactions of residents to nurture stable neighborly relationship. Thus the compact development mode and scarcity of space may have reinforced the social role of UGS in the context of the OP community structure.

The Old-core residential (OR) includes lower-middle income inner-city precincts situated in the districts (Figure 1). They are typical of the extensive high-density but rather low-quality private residential areas (Yeung-Law and Lau, 1988; Kinoshita, 2001). The mixed land-use pattern is composed by a gridiron town plan filled with tightly packed buildings and roads. The congested pavements and vehicular traffic are exacerbated by busy retail, hawking and office uses juxtaposing the residences. The rather cluttered, messy and noisy ambience is compounded by security and hygiene problems (Yau Tsim Mong Federation of Association, 1999; Democratic Alliance for Betterment of Hong Kong, 2000).

The scattered and tiny UGS pockets, trapped between dilapidated tenement blocks, are poorly designed with excessive hard cover and little vegetation. The recent provision of tiny parks (usually $<50 \mathrm{~m} 2$; Xue et al., 2001), on sites vacated by demolished old buildings, serves to compensate for past defective planning. The overdeveloped district with a fossilized tight town plan has no prospect of installing a sizable park. Such tiny pockets are seriously impinged by the surrounding poor environmental conditions such as vehicular emission, noise and heavy shading.

The undesirable community milieu may influence the diversity of park users rather than 
excluding them. Groups of people commonly engage in gambling, chess and chatting in the parks, restricted to blue-collar middle-aged and elderly men. Some sites serve as loci for local lay culture and hawking that attract many residents and tourists. Proximity to diversified activities has added value to the UGS, which provide convenient recreational venues to the working class and the unemployed despite the poor environmental, security and hygiene conditions (Lam et al., 2004). Tolerant and oblivious of the poor park conditions, they visit more for social fulfillment rather than aesthetic enjoyment.

The Suburban Residential community (SR) includes comprehensively developed private housing estates at the city fringe contiguous to the urban core (Figure 1), catering to middle-income families. The community profile is similar to the middle-class residential sites surveyed by Lee (1999). The middle-class lifestyle pays more attention to health and mental comfort. The mid-aged household heads would spend more time with family members, suggesting an expectation for family-oriented communal gardens. Higher environmental consciousness also characterizes the middle-class. Common explanatory variables include education attainment and income level. Admiration for nature may be more than a function of socioeconomic variables or immediate environmental needs as are usually presumed. A local study has indicated that it is a subjective disposition not necessarily based on cognitive appeals (e.g. environmental knowledge) (Chan and Yam, 1995). SR may offer alternative explanations. Middle-class residential communities in Hong Kong are a unique urban phenomenon. A decent number of middle-class individuals reside in packed high/medium-rise towers. SR consists of three large clusters of establishments, with more than thirty 20-storey buildings each, professionally managed within defined neighborhood boundaries. These sites contain intra-estate greenspaces that are well-vegetated and managed. Residents share estate infrastructures, regular estate-wide social activities, and property management monitoring duties. Coupled with a shared feeling of pride, the mutually dependent membership nurtures a sense of community (Lee, 1999).

New-town Public Housing (NP) comprises two public housing estates, situated in leapfrog suburbs located well away from the old urban core (Figure 1). The latest generation of new towns is well-planned with generous provision of parks with fine landscape (Chan et al., 1997; Leung, 1999). Thank to the deliberate high-density development policy, both estate and household environments are in a fairly crowded condition. Tin Shui Wai, one of the NP sites, has a high population density of 62,790/km2. The high-rise blocks exceeding 30 storeys accommodate mainly young working-class families, including many new migrants from mainland China.

Recent studies have affirmed that the crowded household condition in Hong Kong has widely encouraged visits to public open spaces (Kinoshita, 2001; Lam et al., 2004; Lau et al., 2005), adding to earlier studies (Mitchell, 1971; Liang, 1975). It is described as a push from cramped homes to outdoor communal spaces (Lam et al., 2004). Furthermore, vegetation quantity of UGS could enhance recreational attractiveness and visit frequency (Bjerke et al., 
2006; Neuvonen et al., 2007). With liberal supply of greenspace, ideally NP should be conducive to park patronage, further prompted by household constrains. On the other hand, overseas experience suggests that investment of public funds in new town's UGS may suffer from the risk of a planned wasteland (Cybriwsky, 1999). A reason potentially relevant to NP is that local parks are not designed to foster social interactions and to facilitate the social integration of migrants into society (Jay and Schraml, 2009). Failure to establish community ties may weaken recognition of UGS as an intimate neighborhood component. New generations may also be less interested in park visiting. These opposing factors offer a cutting point to investigate greenspace consumption in NP.

The four residential communities were chosen to represent some principal gradients of residential accommodation in Hong Kong (Table 1) based on official demographic and socioeconomic statistics (Census and Statistics Department, 2007, 2010) and field evaluation. Firstly, they form an income spectrum from low (OP and NP) to lower-middle (OR), to middle (SR). Secondly, they denote the major division of the housing stock, namely government subsidized public housing (OP and NP) versus private housing (OR and SR). Thirdly, they compare two pairs of housing quality, namely old-poor (OP) versus new-fair (NP) public housing, and old-poor (OR) versus new-fair (SR) private housing. Fourthly, they contrast between high-density inner-city area (OP and OR), and well-planned contiguous suburb (SR) and leapfrog suburb (NP). The main working hypotheses to be tested for each community are listed in Table 2.

\section{Method}

A questionnaire with mainly close-ended questions was designed to explore residents' perception of UGS and park-visit habits. The first part probed perception of UGS functions and negative impacts. The second solicited the frequency, companionship and stated purpose of UGS visits. The third gauged the perception of community quality. The fourth evaluated views on UGS quality and preference for greenspace design. The final part gathered respondents' socioeconomic information.

Household units were randomly chosen from the study sites. One resident aged 18-70 from each unit was invited for a 20-minute face-to-face interview. A pilot test of 20 individuals provided real-world experience and feedback to refine the questionnaire. Eight university students were trained as interviewers. The surveys were conducted in the local dialect (Cantonese) in January-March 2008 on Saturday and Sunday afternoons.

The analysis was focused on the extent of, and the impact of community attributes on, community variations in terms of residents' perception. The differences between the four residential communities were analyzed by the $\mathrm{F}$ test by comparing their respective group means. The scores for perceived community quality were aggregated to predict the stated importance of UGS by multiple regression. Effects of individual attributes were examined in terms of non-parametric correlations (Spearman's rho two-tailed). Chi-square contingency test 
was used to compare the impacts of perceived community quality and greenspace features on visit frequency. For aggregate measures, missing values are replaced using linear interpolation method. The SPSSPC software version 15 was employed in statistical analyses.

\section{Results}

Comparison of demographic traits and community quality

The survey yielded 495 completed interviews, with 134 from OP, 114 from OR, 121 from SR and 126 from NP, with 35-51\% response rates. The four communities differ in terms of six socioeconomic traits, confirmed by Chi-square tests (all $\mathrm{p}<0.05$ ): age, income, education, retirement status, residence length, and children in family.

OP has the largest proportion of elderly residents, followed by SR. NP is the youngest and OR the middle. SR is the wealthiest with $46 \%$ of the household income $>$ HK\$40,000/month (HK\$7.8=US\$1.0). OR has more lower-middle income households earning HK\$20,000-40,000/month. Over 40\% of OP and NP households earn $<$ HK\$10,000/month.

Education attainment follows the income pattern. Nearly half (48\%) of SR residents have tertiary qualification but only 35\% for OR, and $<25 \%$ for OP and NP. OP has $20 \%$ retired residents, followed by SR (17\%), NP (14\%) and OR (8\%). Many OP residents have lived in current residences over 25 years. Most OR, SR and NP residents have dwelt there for 5-15 years. More residents in OR and SR, mainly middle-aged, have children under 12 than OP and NP.

The perception towards the general quality of neighborhood and domestic living environment ('community quality attributes') was assessed by ten questions (Table 3). A higher score denotes a more satisfied state. To reflect relative importance, weighted percentage is computed by dividing mean score by the highest one in the same row. Nine items showed statistically significant differences between communities.

C1 to C3 are environment-related attributes, namely air quality, noise and landscape quality. SR with attractive sea and mountain views and little air-quality and noise problems is rated higher than the rest. Ranked second is NP, which benefits from the former rural land with pleasant environment and good planning. OR is located in old and congested inner-city areas with poor environment. SR residents are more satisfied with environmental hygiene (C4) and public security (C5), but the ratings are lower for other communities due to incompatible land uses aggravated by poor management. NP tops the league only in the accessibility to entertainment facilities (C6).

OP residents have strong relationship with neighbors (C7). Fewer OR residents are familiar with their neighbors. The fact that the neighborhood boundary is blurred with unfavorable conditions for social interaction and cohesion may offer an explanation. SR and NP lie between the extremes. More SR residents discern a lower urban density (C9), but OP and OR perceive the overcrowding problem. Many OP residents observe inadequate indoor living space (C10), echoing the tight space provision in government-subsidized public rental 
housing. Fewer people in SR convey this problem.

Overall satisfaction of community quality is denoted by an aggregate index, COMMQUAL, which summed the scores of the ten attributes with a reasonable reliable scale (Cronbach's Alpha $=0.70$ ). SR captures the highest rating, reflecting a high level of satisfaction. NP and OP similarly score lower than SR, but differ from each other in individual items. OR contrasts SR with a more negative about the living environment.

Community quality attributes are factor analyzed based on the principal component method and varimax rotation. Four factors were yielded, including Urban Morphology (C1, C2, C3, C4, C5 and C9), Community Membership (C7 and C8). C10 and C6 individually form the remaining two factors.

\section{Comparison of community preferences}

This section analyzes the community effects on preferences for UGS. The perceived importance of 18 UGS functions is compared (Table 4), with eight items yielding significant differences. SR stands out, indicating appreciation of UGS for outdoor exercises (F1) and children's playgrounds (F3). Social interactions between neighbors (F2) receive greater emphasis from OP. Private housing (OR and SR) inhabitants perceive green buffers between buildings (F5) as more important than public housing (OP and NP). They stress property value (F7), which is irrelevant to public rental housing (OP and NP). The UGS ecosystem functions (F10, F13 and F14) are more appreciated by SR than OR, as it is trapped in the urban core with cramped and poor environment and inhabited by individuals who presumably are environmentally less conscious.

For negative effects of UGS, the better-off communities (OR and SR) hold contrasting views (Table 5). OR is more negative on gang problems (N2), occupying urban spaces (N3) and blocking light (N4), and to a lesser extent, dark hiding places (N1) and messy organic litter (N5). However, SR indicates positive perception of UGS in all five parameters. The cramped community condition of OR may have prompted the dissatisfaction with some greenspace features. Similarly, OP with degraded environment also harbors more negative views.

OR and SR are frequent users of UGS, with $>50 \%$ patronizing more than weekly (Table 6). OP displays a more polarized pattern, with the largest proportion of the most frequent (at least once per day) and the second largest of least frequent (less than monthly) users. NP has less frequent visitors with less than $40 \%$ at more than weekly frequencies. Regarding companions during visits, public housing residents with low income (OP and NP) are more accompanied by neighbors or friends. Better-off OR and SR residents mainly go with children and other family members.

For the stated purpose of visit, four attributes yield significant differences between communities (Table 7). OP activities are relatively more socially oriented, with more chatting or gathering with friends (H6), and NP follows to a lesser extent. More residents in middle-income SR visit parks for clean air (H2), tranquility and relaxation (H4) and natural 
landscape (H5), particularly when comparing to NP. OR displays a greater tendency of taking children to playgrounds than the aged OP and youthful NP.

For problems associated with the UGS near residences (Table 8), all communities regard sports facilities (P7) to be inadequate, resulting in no significant difference between them. The discerning SR strongly indicates satisfaction with site area (P3), seats or pavilions (P4), hygiene condition (P5), too many people (P6), and greenery (P8). In contrast, OR holds greater discontent with these aspects. Generally, not much variation is found between OR, OP and NP. Their views converge in landscape quality (P1), hygiene condition (P5) and too many people (P6). NP agrees that the sites are located too far (P2). OP and SR are less concerned about this issue.

Regarding preferences for park design features, the four communities consistently want more trees than sports facilities and seats (Table 9). The inclination for seat arrangement is more diverse with significant differences between communities, although dispersed seats are overwhelmingly more popular. Demand for clustered seats is greater in lower-income OP and NP than OR and SR. For park size, fewer residents like small parks. More inner-city residents (OP and OR) prefer a single large park than the suburbanites (SR and NP).

Comparisons between community pairs, using post hoc comparisons of observed means, could indicate the magnitude of variations in preferences. Bonferroni tests were conducted by taking the three aggregate measures, namely IMPORTANCE, NEGEFFECT and SITEPROB as proxy for their preferences (Cronbach's Alpha $=0.87,0.75$, and 0.78, respectively). Based on the significance of mean difference, SR exerts distinctive community effects in NEGEFFECT and SITEPROB $(\mathrm{p}<0.05)$. SR credits UGS with higher importance than NP $(\mathrm{p}<0.05)$.

A closer look at individual functions or visit purposes reveals more differentiations. For instance, old public housing (OP) has a stronger preference than its new counterpart (NP) for interaction with neighbors (F2, $\mathrm{p}<0.05)$. OR residents visit parks generally more often than NP $(\mathrm{p}<0.05)$. In the old urban core, public housing (OP) surpasses private housing $(\mathrm{OR})$ in wanting to chat or gather with friends (H6, $\mathrm{p}<0.01$ ). Nevertheless, OP and OR share their concern more than SR that greenspaces would occupy urban spaces (N3, $<<0.01$ ). Public-housing communities (OP and NP) are less concerned than OR and SR about the positive impact of UGS on property value $(F 7, \mathrm{p}<0.01)$.

Table 10 summarizes the strength of responses of each community relative to the rest. The middle-income SR has consistently strong affinity (perceived importance) for UGS in most aspects, except a few social benefits such as fostering neighborly interaction, and dispelling negative perceptions. Regarding purpose of visit, SR mainly seeks environmental and aesthetic enjoyment with an emphasis on family life. OR holds more skeptical views about negative effects but it does not dampen visit frequency. OP has relatively stronger preference for only a few aspects, such as promoting neighborly interactions, but is fairly sensitive to negative impacts. For the purpose of visit, OP more embraces social interaction and chatting with 
friends. NP is somewhat indifferent to positive and negative aspects of UGS, an attitude echoed by their least frequent park patronage.

Overall, more significant observations are contributed by SR. The other three communities demonstrate similar views or preferences in many aspects, although they differ in some individual items. Differential community effects are mainly issue-based with moderate strength.

\section{Identification of effective community quality attributes}

To explain the divergent public perception of greenspaces, we linked the above observations to community characteristics. Initial analysis affirmed strongly significant correlations between COMMQUAL, and IMPORTANCE $(\mathrm{r}=0.163, \mathrm{p}<0.01)$ and NEGEFFECT $(\mathrm{r}=-0.155, \mathrm{p}<0.01)$, justifying further analysis. Two regression models were constructed to predict the perception scores, with the factorial factored community quality attributes, personal socioeconomic traits, visit frequency and recognition of site problems as dependent variables.

.The regression models affirmed that the community quality factors (Urban Morphology and Community Membership) exert strongly significant effects (Table 11). They solely contribute 8\% variations to IMPORTANCE and improve the explanatory power of the model. This result supports the hypothesis that public perception of UGS is affected by community quality attributes.

Individual community quality attributes are further examined to provide possible explanations as to what contribute to the varying emphases. Space limit does not allow a full statistical report. For brevity, the following analysis focuses on the forgoing statistically significant observations. Corresponding to the earlier formulated hypotheses, mainly representative features are examined, in terms of significantly correlated and relevant community quality attributes.

OP residents have stronger preference for chatting and gathering with friends and clustered seats that facilitate social interactions. This function (F2) is associated with the strong social connections that characterize the old community. Neighborhood relationship (C7) has the strongest relationship with setting for social interaction (F2) $(r=0.223, p<0.01)$. Perceived urban density (C9) is negatively related to F2 $(\mathrm{r}=-0.105, \mathrm{p}<0.05)$, implying that a compressed urban milieu could foster socializing activities in public open areas. Other cognate factors such as better landscape quality (C3) are also beneficial to socialization in parks $(r=0.138, p<0.01)$.

Elevated concern about the community (C8) $(r=0.207, p<0.01)$ and strong neighborhood relationship (C7) $(\mathrm{r}=161, \mathrm{p}<0.01)$ could increase visits to UGS, where residents could communicate and share information. C7 remains powerful in predicting the visit purpose of, chatting or gathering with friends $(\mathrm{H} 6)(\mathrm{r}=0.165, \mathrm{p}<0.01)$.

OR residents are fairly sensitive to UGS safety issues, connecting dark and hiding places (N1) to public security (C5) ( $r=-0.093, \mathrm{p}<0.05)$, urban density (C9) ( $r=-0.156, p<0.01$ ), and concern about the community (C8) $(\mathrm{r}=0.101, \mathrm{p}<0.05)$. The negative correlations indicate that 
deteriorating public security and overcrowding may induce antagonism towards UGS. Likewise, the worry about gang activities in parks (N2) is related to public security (C5) $(\mathrm{r}=-0.167, \mathrm{p}<0.01)$ and urban density (C9) $(\mathrm{r}=-0.162, \mathrm{p}<0.01)$.

Perception of high urban density is associated with the impression that trees would occupy too much urban spaces and block light. The belief that UGS would 'waste' the limited land resource (N3) is relatively strong in OR. The strength of this thought varies with perceived urban density (C9) $(r=-0.093, p<0.05)$, suggesting that the cynicism is nurtured by the chronic overcrowding problem. C9 is also correlated with the view that trees block light (N4) (r=-0.115, $\mathrm{p}<0.05)$. The tightly packed buildings with narrow streets have notably reduced sunlight access to generate disapproval of further dimming by vegetation. Concern about messy organic litter (N5) increases with deteriorating landscape quality (C3) $(r=-0.150, p<0.01)$.

SR residents importantly view UGS as children's playground. This function (F3) is correlated with noise (C2) $(r=0.114, p<0.05)$, environmental hygiene $(C 4)(r=0.096, p<0.05)$, public security (C5) ( $r=0.128, p<0.01)$, and perceived urban density (C9) $(r=0.114, p<0.005)$. Those who thought that the environmental hygiene is good, neighborhood is safe, and noise and crowding are not problematic, tend to rate F3 high. The desires for environmental and aesthetic enjoyment are facilitated by typical SR community quality attributes. There is a positive relationship between clear air (H2) and landscape quality (C3) $(r=0.133, p<0.01)$, enjoy the tranquility and relax (H4) and air quality (C1) $(r=0.116, p<0.01)$, and enjoy the natural landscape (H5) and noise level (C2) (r=0.135, p<0.01).

SR residents highly appreciate the ecological role of urban nature. It could be a subjective disposition not exclusively a function of socioeconomic factors such as education level. A regression analysis was conducted to investigate the extent to which the socioeconomic and community quality attributes could predict the perceived importance of seven environmental functions of UGS (dependent variable $=\Sigma F 9-F 15$, Adj. R2=0.06). It indicates that education attainment and other socioeconomic factors are not significant predictors ( $p>0.05)$. The effects of neighborhood relationship (C7) and concern about the community (C8) are stronger and significant $(\mathrm{p}<0.01)$. Presumably causally related pairs prove to be inert. The perception of air quality (C1) does not correlate with the perceived importance of reducing air pollution (F10) $(r=0.041, p>0.1)$. Noise (C2) also does not correlate with abating noise (F11) $(r=0.011, p>0.1)$.

$\mathrm{NP}$ is located in the suburb with a generous supply of greenspaces. Chi-square test indicates significant association between preferred park size and adequacy of greenery (P8) (X2=18.394, $\mathrm{p}<0.01$ ). The desire for a large park is dampened if a community has sufficient greenery. The relationships between visit frequency and UGS quality (using the surrogate of site problems) and community quality are investigated by cross-tabulations (Table 12). Except venue location, park quality is not associated with visit frequency (Table 12, left side). With four significant attributes $(\mathrm{p}<0.05)$, community quality has stronger effects on visitorship (Table 12, right side). They indicate that positive perception of the community could motivate park visits. The reverse interpretation is less likely, that is, more park visits could strengthen 
sentimental attachment and positive views on the community.

Visit frequency is suggested to be a function of flat size. However, the association between self-assessed indoor living space (C10) and visit frequency (VISITFREQ) is not significant $(\mathrm{X} 2=10.965, \mathrm{p}>0.05, \mathrm{~N}=493)$. The response of the generally younger NP residents hints an alternative interpretation. Extracting data of residents older than 50 only, the association becomes stronger and significant (X2=21.646, $\mathrm{p}<0.05, \mathrm{~N}=137)$, indicating the age-dependent effect of flat size.

\section{Discussion}

\section{Neighborhood and friendly green 'places' in $O P$}

The strong neighborhood ties among OP residents are linked to the salient social role of UGS. The finding that neighborhood relationship is a powerful predictor adds value to the literature. Western scholars such as Kuo et al. (1998), Kweon et al. (1998) and Kearney (2006) found that the abundance of vegetated open areas could enhance neighborhood ties and sense of community. Our study of old Asian neighborhoods suggests a possible reverse relationship. Strong neighborhood attachment could reinforce residents' desire for greenery. Abundance of greenspace, being not a fair descriptor of OP, is unlikely a strong contributing factor.

Such a relationship is likely to be co-evolutionary and mutualistic. Many Asian geographers have affirmed the role of communal experience. Tuan (1974), for example, argued that human sentimental attachment to the surrounding nature may represent their loyalty to home. People's emotional ties to others and concerns about the place may be translated to an affinity to the environment where they live and share. Appreciation of natural elements in a community is thus entangled with a sense of neighborhood, accumulated through daily social contacts between community members. UGS as communal meeting venues are construed as an important neighborhood element not merely for open-space provision but also a metaphor of the neighborhood. As such, the expressed importance of a group of trees in an old community is derived from the provision of space (open areas under the tree) as well as a sense of place (collective memory and sentimental attachment). Green open spaces therefore could nurture social capital which, in turn, could reinforce their perceived value.

This interpretation is consistent with the community history and profile of old public housing estates in Hong Kong. The nurtured communal experience resulted in strong social bonding and cohesion, which has been translated into an affinity for greenspace. The UGS in OP can be construed as a social construct manifested as neighborhood green 'places'. The crowded indoor and outdoor conditions have shrunk both the physical and social distance between residents. That the UGS are seen as neighborhood places, not merely public spaces, and exhibit a specific social quality, is related to the strong neighborhood relationship and perceived importance of UGS. The value of the neighborhood and the attached greenspaces have grown and reinforced each other through time, rendering a culturally intertwined, inseparable and enduring entity. 


\section{Stressed use of OR greenspaces}

OR residents generally harbor relatively negative attitude towards UGS. Perceived neighborhood quality could explain the heightened concerns. The two OR sites are notorious for urban blight related to problems of hygiene, public security, overcrowding and derelict buildings. The sense of fear due to district-wide poor security status has molded UGS perception.

Some pocket parks in OR are adjacent to the loci of illicit underground activities. The negative OR views towards UGS are affected by the poor social environment of the districts, which is corroborated by a recent study (Democratic Alliance for Betterment of Hong Kong, 2000). Respondents were reluctant to visit the tiny parks because of rather rampant security problems, often associated with illegal gambling, homeless people, vandalism, and prostitution. Proximity to such unseemly activities may threaten park users, especially female and children. Such neighborhood leisure sites have degenerated into bases for illegal and unbecoming activities (Xue et al., 2001). The quality of the local social landscape has tainted the public image of the local UGS to the extent that they are widely averted. The small UGS should be intimately interwoven into the local residential fabric to meet day-to-day outdoor recreational needs (Joardar, 1989), yet many residents are hesitant to venture into them.

Our data suggest a rather ambivalent disposition. OR residents have demonstrated tolerance and adaptation, reflected in their being the most frequent UGS visitors amongst the four communities. The substandard parks have not deterred their assiduous use. Crowding-tolerant users welcome some social stimulation from encounters with others (Arnberger and Haider, 2005). To many people, human proximity and contacts are warmly desired, particularly in Asian societies (Tuan, 1977). The heterogeneous park users could enhance the stimuli for people who relish being in a crowd, with the apparently unpleasant conditions serving as a selection force. Although on-site and site-proximal urban defects have discouraged some potential park users, the lure of the micro-social environment, cordial interactions and associated subculture has selected a cohort of flaw-tolerant users who are insensitive to or comfortable with the ostensibly chaotic settings.

An unexplored issue worthy of further research concerns about the ambivalence of tolerant users and the limits on on-site activities in suchlike parks. Tolerant users adapt their sensory and social predilection to make the best use of the low-caliber green plots. With minimal management intervention and in the laissez faire spirit, they create a novel and cloistered social ambience in the cramped sites to serve as their almost semi-private leisurely niches. The catalyst for congregation originates from the socio-cultural lure rather than inherent site design. Site quality has been relegated to an immaterial status, overwhelmed if not usurped by the more pressing need for open and informal communal spaces.

Nevertheless, the literal usurpation of the precious local green space resources by a small cohort of residents, tantamount to a form of territorialisation (Joardar, 1989), could present a 
socially unhealthy phenomenon that deserves further investigation. The unwilling non-users are deprived of access to local green spaces a key community service (Erkip, 1997). The limited area of individual sites could not permit partition by seams into an intricate spatial pattern to accommodate divergent user needs. The homogeneously poor sites have become green magnets (as used by Gobster, 1998) for a cluster of homogeneous activities with little inter-site variations. Such sites have been transformed by citizens into a variant of green wall that selectively rejects certain segments of the community (Solecki and Welch, 1995). Thus the lack of social inclusiveness of OR parks remains a vexing issue.

\section{Family garden for discerning middle-class $S R$}

SR residents recognize UGS as a place for family activities and aesthetic enjoyment, and less so for social interactions. This is related to the better landscape quality management. Their green spaces are largely privatized with controlled access, offering better security than public UGS (Cybriwsky, 1999). The high quality environmental and social setting has rendered the green sites suitable for family consumption.

Perceptions of environmental hygiene and public security are correlated with three visit purposes. Since SR is endowed with well-managed and landscaped greenspaces, the residents are tempted to use them. Their high visit frequency constitutes an interesting contrast with the poorly landscaped OR. SR hold more positive attitude towards UGS environmental functions, some of which are not much appreciated by OR residents with a similar education attainment $(\mathrm{X} 2=3.802, \mathrm{p}>0.05)$. Typical physical community and socioeconomic variables are not good predictors.

The sense of neighborhood is a subjective expression of one's sentimental attachment to the living place and people. Likewise, concern about the community reflects identification with and motivation to engage in community affairs. The positive outlook and attachment may extend from UGS to the neighborhood. The appreciation of the ecological role of UGS is partly driven by the feeling as an integral member of the neighborhood. In contrast, the ecocentric argument that emphasizes immediate environmental needs may not be applicable. Concerns about key urban environmental problems in Hong Kong, namely, air pollution and noise, have not induced recognition of the remedial functions of UGS. The awareness of UGS ecological role in SR contains not only cognitive but also experiential and sentimental elements.

\section{New town as unattractive compact garden city in NP}

The lower visit frequency in the youthful NP could be explained by an age-dependent push effect. The elderly residents are more inclined to expand their living space by visiting UGS nearby. The younger people would find outlets beyond local UGS, such as fitness centers, karaoke bars and shopping malls. Their rental public housing units are assigned by the government, meaning that they may not willingly live in the new town. They tend to treat their abode as a lodging town and seek recreational opportunities and other urban services outside. 
On weekdays, they leapfrog between school or work place in the old city core and home (Hui and Lam, 2005). On weekends and holidays, similarly they leapfrog to the city core to satisfy their leisure pursuits. This result verifies a selective push effect, the expression of which varies by life style which is contingent on age (Jorgensen and Anthopoulou, 2007).

Preference for a large park is weaker in NP than the two inner-city communities (OP and OR). New-town planning in Hong Kong has incorporated the notion of compact garden city with generous greenspace provision. Thus NP has no strong urge to have more UGS. Planned greenspace in NP is of comparable, if not better, quality as SR, but rendered significantly lower importance by its residents. The apathy extends to perception of UGS as an important common asset, a threat or a problem. It is ironical that the abundant and high-quality greenspaces in this community have failed to attract enthusiastic patronage or support.

Possible explanations could be sought from two observations on Table 12. Air quality (C1) and noise (C2), as prominent urban defects, have no significant impacts on park use. This corroborates with Lam et al. (2004) that Hong Kong people are conditioned to tolerate poor environmental quality around parks, which has little effect on visitation. However, the two social factors, namely neighborhood relationship (C7) and concern about the community (C8), exert significant positive influence on park visit. The effect of neighborhood relationship has been discussed in preceding sections. The concern about the community could be explained. Urban parks offer a daily communication platform for inhabitants to exchange information and discuss about their community. They provide opportunities for activities that could nurture good citizenship, social consciousness, and sense of ownership. Loyalty and attachment to the community could engender through close interaction and cooperation amongst residents (Cranz, 1982).

NP's relatively low park usage could be evaluated. The population is rather youthful, with a different lifestyle and recreational preference vis-à-vis the older counterparts. Age is positively correlated with concern about the community (C8) $(r=0.138, p<0.01)$, indicating young residents' insouciance towards the community. Moreover, as a new town with notable concentration of new migrants from Mainland China, it is beset by weakened community cohesion and identity. Some female migrants avoided parks due to worries about discrimination and taunting by other residents (Ho, 2008, 10 May). Such a disposition echoes the lack of a mature socio-cultural environment, which is necessary for vibrant and equitable greenspace use.

\section{Conclusion}

The perception towards UGS varies according to socioeconomic differentiation of residential communities. Traditionally, suchlike studies tend to focus on demographic characteristics of respondents such as age, income and ethnicity, and park features such as vegetation biomass, species composition, park setting and landscape attributes. Wider issues, such as the social and physical milieu around parks, and the intricate human-nature relationship in the urban context, 
have received less attention. Our Hong Kong study has identified some key contributory factors: income class, life stage, social ambience and urban morphology. The observed significance of community quality attributes is worthy of further research.

Human perception towards nature often extends through the lens of personal circumstances and cognitive response to environmental goods. It serves as a faithful carrier of residents' attitude towards the intrinsic social and physical fabric of their neighborhood, the whole community, country or world. The perception of community issues may extend to subjective evaluation of environmental goods in the community. Affinity for a residential area may engender affinity for its constituent greenspaces. The notion that community features may shape residents' evaluation of UGS calls for more comprehensive research.

Effects of varied community quality attributes on the perception of UGS are significant. The neglected factors could affect UGS use, such as neighborhood relationship, development density, community identity, and street conditions. The present study has investigated ten community quality attributes with differential effects in four residential communities. Two socio-cultural factors consistently exert strong effects, namely neighborhood relationship and concern about the community. They influence UGS perception and visiting patterns. On the other hand, urban features, such as perceived urban density and public security, have more specific effects on UGS perception. Some attributes require a mediating factor to mobilize its effect, such as the adequacy of living space.

The effect of physical attributes such as park facilities on patronage has been emphasized in some studies. However, the inferior greenspaces in OR does not discourage visitors, whereas the generous supply in NP does not attract many visitors. Our findings indicate that park quality could hardly explain variations in park visit frequency. On the other hand, among the ten community quality attributes, only perceived landscape quality (C3), neighborhood relationship (C7) and concern about the community (C8) could significantly predict the perceived importance of UGS. Physical dimensions such as urban density and air quality have more limited effect. Park perception and patronage are more influenced by social rather than physical factors.

Hong Kong's UGS play a different role from their Western counterparts because of its exceptionally compact urban form that permeates from centre to periphery. This is particularly the case for inner-city areas such as OP and OR. The proximity to incompatible land uses and activities has curtailed the traditional role of UGS as tranquil sanctuaries from the hustle and bustle of the city. Local greenspaces are culturally embedded in the social life of the inhabitants. Where the venue and the environs are not attractive, they still manage to attract a sizeable and regular clientele. It is not the meritorious natural or landscape ingredients that pull them to such local green enclaves. Rather, it is the prospect of less tangible social encounters and interplays that lure them repeatedly to such extensions of the home. The neighborhood UGS thus play a salient social role to relieve the chronic limitations in household living space. The propinquity of UGS to residences facilitates the decanting process and social cohesion. 
The role of UGS in compact developing cities could be more humanities-based and socially-adjusted by moving into the multidisciplinary mode. Park planners could incorporate people's experiential needs instead of focusing squarely on the physical aspects of recreation and facilities (L'Aoustet and Griffet, 2001). To create satisfactory settings for daily life are to be created requires a range of experiences, and not just space or specific facilities (Beer et al., 2003). Parks could deliver a sense of place to enhance diverse experience and satisfaction. Kan (1981) and Lam et al. (2004) advocated embedding urban parks into people’s social life and to satisfy the emotional aspects of human life. The demands for natural landscape could go in tandem with community history, collective memory and experience about nature. Deeper understanding of community expectations and aspirations, and public views and motivation of park visitation, is conducive to forging community-specific, relevant and inclusive green-space planning. Moreover, it helps to refine and enrich the bottom-up management mode. The gap between park design and user need (Goličnik and Thompson, 2010), and the inequality in access to parks (Koehler and Wrightson, 1987), should be rectified with the help of research findings. Such enlightened approaches, hitherto hardly developed in Hong Kong and other developing cities, could make UGS more used and useful to the community. 


\section{References}

Arnberger, A and Haider, W (2005) Social effects on crowding preferences of urban forest visitors. Urban Forestry and Urban Greening 3, 125-136.

Barber, A (2002) Planning: Past, Present and Future. Urban Parks Forum, Reading, Berkshire.

Beer, A R, Delshammar, T and Schildwacht, P (2003) A changing understanding of the role of greenspace in high-density housing. Built Environment 29, 132-143.

Benton, T (2008) Environmental values and human purposes. Environmental Values 17, 201-220.

Bhagwat, SA (2009) Ecosystem services and sacred natural sites: Reconciling material and non-material values in nature conservation. Environmental Values 18, 417-427.

Burgess, J, Harrison, CM and Limb, M (1988) People, parks and the urban green: a study of popular meanings and values for open spaces in the city. Urban Studies 25, 455-473.

Census and Statistics Department (2007) Hong Kong 2006 Population By-census Main Report. Government of the Hong Kong Special Administrative Region.

Census and Statistics Department (2010) Hong Kong in Figures 2010 Edition. Government of the Hong Kong Special Administrative Region.han, KW, Hu, WL, Yu, WK, and Li, SCF (1997) City and Housing in Hong Kong: An Assessment from an Urban Sociological Perspective. Joint Publishing (Hong Kong), Hong Kong (in Chinese).

Chan, RYK and Yam, E (1995) Green movement in a newly industrializing area: a survey on the attitudes and behaviour of the Hong Kong citizens. Journal of Community and Applied Social Psychology 5, 273-284.

Coles, RW and Bussey, SC (2000) Urban forest landscape in the UK: progressing the social agenda. Landscape and Urban Planning 52, 181-188.

Cranz, G (1982) The Politics of Park Design: A History of Urban Parks in America. MIT Press, Cambridge, MA.

Cybriwsky, R (1999) Changing patterns of urban public space. Cities 16, 223-231.

Democratic Alliance for Betterment of Hong Kong (2000) Survey Results on the Small Public Parks in Yau Tsim Mong District. Kowloon West Office, Democratic Alliance for Betterment of Hong Kong, Hong Kong (in Chinese).

Dooling, S, Simon, G and Yocom, K (2006) Place-based urban ecology: a century of park planning in Seattle. Urban Ecosystem 9, 299-321.

Drenthen, M (2009) Ecological restoration and place attachment: Emplacing non-places?. Environmental Values 18, 285-312.

Erkip, E (1997) The distribution of urban public services: the case of parks and recreational services in Ankara. Cities 6, 353-361. 
Gobster, PH (1998) Urban parks as green walls or green magnets? Interracial relations in neighborhood boundary parks. Landscape and Urban Planning 41, 43-55.

Goličnik, B and Thompson, CW (2010) Emerging relationships between design and use of urban park spaces. Landscape and Urban Planning 94, 38-53.

Grove, JM, Troy, AR, O’Neil-Dunne, JPM, Burch WR Jr, Cadenasso, ML and Pickett, STA (2006) Characterization of households and its implications for the vegetation of urban ecosystems. Ecosystems 9, 578-597.

Hayward, DG and Weitzer, WH (1983) Understanding urban park users: a key to effective planning and management. Parks and Recreation Resources 2, 24-27.

Hung, R (2010) Journeying between home and nature: A geo-phenomenological exploration and its insights for learning. Environmental Value 19, 233-251.

Ho, SY (2008) The CSSA woman: living in Hong Kong is worse than farming in my village! Mingpao Daily (10 May 2008), Hong Kong (in Chinese).

Hui, ECM and Lam, MCM (2005) A study of commuting patterns of new town residents in Hong Kong. Habitat International 29, 421-437.

Jay, M and Schraml, U (2009) Understanding the role of urban forests for migrants: uses, perception and integrative potential. Urban Forestry and Urban Greening 8, 283-294.

Jim, CY (2000) The urban forest programme in the heavily built-up milieu of Hong Kong. Cities 17, 271-283.

Joardar, SD (1989) Use and image of neighborhood parks: a case of limited resources. Environment and Behavior 21, 734-762.

Jorgensen, A and Anthopoulou, A (2007) Enjoyment and fear in urban woodlands does age make a difference? Urban Forestry and Urban Greening 6, 267-278.

Kan, WSA (1981) Implications of concentrated utilization of local facilities and services in public housing estates. In: King, AYC and Lee, RPL (Eds), Social Life and Development in Hong Kong. Chinese University Press, Hong Kong.

Kearney, AR (2006) Residential development patterns and neighbourhood satisfaction: impacts of density and nearby nature. Environment and Behavior 38, 112-139.

Kinoshita, H (2001) The street market as an urban facility in Hong Kong, In Public Places in Asia Pacific Cities: Current Issues and Strategies, P Miao (ed.). Kluwer Academic Publishers, Dordrecht.

Koehler, DH and Wrightson, MT (1987) Inequality in the delivery of urban services: a reconsideration of the Chicago Parks. The Journal of Politics 49, 80-99.

Kuo, FE, Sullivan, WC, Coley, RL and Brunson, L (1998) Fertile ground for community: inner-city neighborhood common spaces. American Journal of Community Psychology 26, 823-851.

Kweon, BS, Sullivan, WC and Wiley, AR (1998) Green common spaces and the social integration of inner-city older adults. Environment and Behavior 30, 832-858. 
Lam, KC, Baniassad, E, Hui, WC and Chow, K (2004) Parks, People and the Environment: A Study of the Environmental Quality and Visitor Behavior in Parks and Open Spaces in Hong Kong. Centre for Environmental Policy and Resource Management, Chinese University of Hong Kong, Hong Kong.

Lambert, D (2002) Urban Parks Programme. Heritage Lottery Fund, London.

L'aoustet, O and Griffet, J (2001) The experience of teenagers at Marseilles'skate park. Cities 6, 413-418.

Lee, J (1999) Housing, Home Ownership and Social Change in Hong Kong. Ashgate, Aldershot.

Lee, J and Yip, NM (2006) Public housing and family life in East Asia: housing history and social change in Hong Kong, 1953-1990. Journal of Family History 31, 66-82.

Leung, MY (1999) From Shelter to Home: 45 Years of Public Housing Development in Hong Kong. Hong Kong Housing Authority, Hong Kong.

Liang, CS (1975) Overcrowding and environmental deterioration: The case of Hong Kong. Journal of The Chinese University of Hong Kong 3, 219-253.

Lo, AY and Jim, CY (2010) Willingness of residents to pay and motives for conservation of urban green spaces in the compact city of Hong Kong. Urban Forestry \& Urban Greening 9, 113-120

Mitchell, RE (1971) Some social implications of high density housing. American Sociological Review 29, 210-217.

Müller-Perband, E (1979) The modern town park in Germany. In: Laurie, IC (Ed), Nature in Cities. Wiley, New York, pp. 297-326.

Noël, JF, O'Connor, M and Tsang, JKS (2000) The Bouchereau woodland and the transmission of socio-ecological economic value. Ecological Economics 34, 247-266.

Palmer, JF (1984) Neighborhoods as stands in the urban forest. Urban Ecology 8, 229-241.

Solecki, WD and Welch, JM (1995) Urban parks: green spaces or green walls? Landscape and Urban Planning 32, 93-106.

Tuan, YF (1974) Topophilia: A Study of Environmental Perception, Attitudes, and Values. Prentice-Hall, Englewood Cliffs, NJ.

Tuan, YF (1977) Space and Place: The Perspective of Experience. University of Minnesota Press, Minneapolis, MN.

Walker, SE and Duffield, BS (1983) Urban parks and open spaces: an overview. Landscape Research 8, 2-12.

Xue, CQL, Manuel, KKK and Chung, RHY (2001) Public space in the old derelict city area - a case study of Mong Kok, Hong Kong. Urban Design International 6, $15-31$. 
Yau Tsim Mong Federation of Association, (1999) Survey Report of the

Environmental Hygienic Condition in Yau Tsim Mong District. Yau Tsim Mong Federation of Association, Hong Kong (in Chinese).

Yeung-Law, KCA and Lau, KY (1988) A Report of the Exploratory Study on the Environmental Issues of the Aging Buildings in Mong Kok District. Hong Kong. Mongkok District Council, Hong Kong (in Chinese).

Young, RA and Flowers, ML (1982) Users of an Urban Natural Area: their Characteristics, Use Patterns, Satisfactions, and Recommendations. Forestry Research Report, Department of Forestry, Agricultural Experiment Station, University of Illinois at Urbana-Champaign. 
Differential community effects on perception and use of urban greenspaces

List of figure and tables

Fig. 1. Locations of the 10 study sites of the four residential communities.

Table 1 Summary of the main features of the study areas composed of four dominant residential communities in Hong Kong.

Table 2 Main working hypotheses of the study

Table 3 Comparison of perception towards community quality attributes amongst the four residential communities.

Table 4 Comparison of perceived importance of the functions of urban greenspaces amongst the four residential communities.

Table 5 Comparison of perceived negative effects of urban greenspaces amongst the four residential communities.

Table 6 Comparison of the frequency and companion of visits to urban greenspaces amongst the four residential communities.

Table 7 Comparison of the stated purpose of visiting urban greenspaces amongst the four residential communities.

Table 8 Comparison of the site problems of the urban greenspaces near residences amongst the four residential communities.

Table 9 Comparison of the preference for park design features amongst the four residential communities.

Table 10 Summary of the relative strength of the perception, habit and preference concerning urban greenspaces in the four residential communities.

Table 11 Regression models for the perception of the importance and negative effects of urban greenspaces.

Table 12 Chi-square contingency test results of the cross-tabulation between visit frequency versus site problems of urban greenspaces near residences and community quality attributes. 


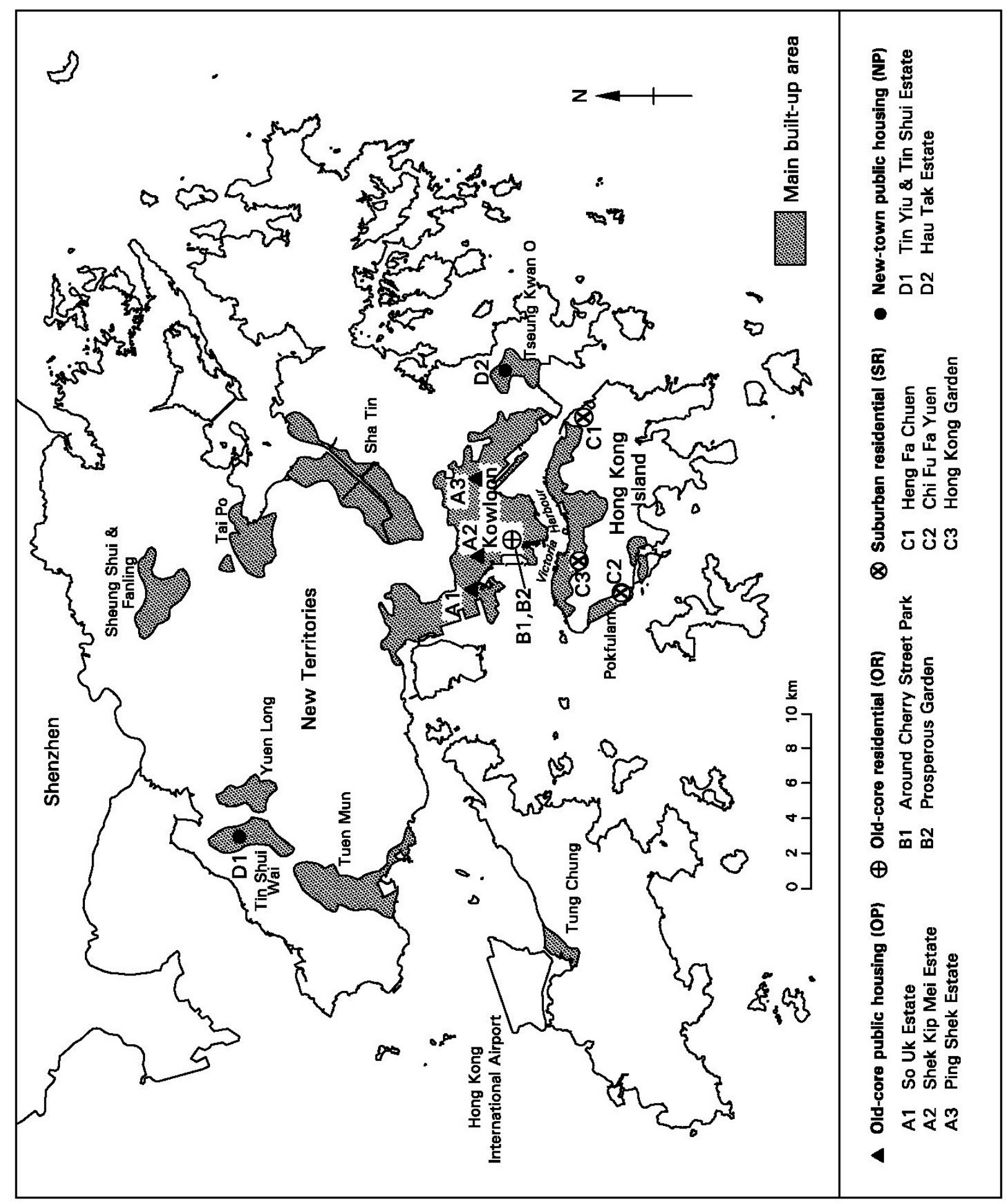

Fig. 1. Locations of the 10 study sites of the four residential communities. 
Table 1

Summary of the main features of the study areas composed of four dominant types of residential communities in Hong Kong

\begin{tabular}{|c|c|c|c|c|}
\hline \multirow[b]{2}{*}{ Main community feature } & \multicolumn{4}{|l|}{$\begin{array}{l}\text { Community } \\
\text { type }\end{array}$} \\
\hline & $\begin{array}{l}\text { Old-core Public } \\
\text { Housing (OP) }\end{array}$ & $\begin{array}{l}\text { Old-core } \\
\text { Residential } \\
\text { (OR) }\end{array}$ & $\begin{array}{l}\text { Suburban } \\
\text { Residential (SR) }\end{array}$ & $\begin{array}{l}\text { New-town } \\
\text { Public Housing } \\
\text { (NP) }\end{array}$ \\
\hline Location & Urban core & Urban core & $\begin{array}{l}\text { Contiguous } \\
\text { suburb }\end{array}$ & $\begin{array}{l}\text { Leapfrog } \\
\text { suburb }\end{array}$ \\
\hline Urban density & High & Very high & Medium & High \\
\hline Housing stock & Public & Private & Private & Public \\
\hline Housing age & Old & Old & Recent & Recent \\
\hline Housing quality & Poor & Very poor & Good & Fair \\
\hline Main Income group & Lower & Lower-middle & Middle & Lower \\
\hline Environmental quality & Poor & Very poor & Good & Moderate \\
\hline Public security \& hygiene & Poor & Poor & Good & Moderate \\
\hline Neighborhood relationship & Good & Moderate & Good & Moderate \\
\hline
\end{tabular}


Table 2

Main working hypotheses of the study

OP The perceived importance and likelihood of socialization in UGS is linked to neighborly interaction and physical factors including domestic development density and indoor spaciousness.

OR Concerns about UGS features are associated with dissatisfaction over community milieu, but intention to visit is not adversely affected.

SR Community quality explains some purposes of visit. The perception of the ecological role of UGS is a function of sense of community. Usual predictors of nature appreciation are less significant than the socially oriented community attributes.

NP Visit frequency is associated with household size and community quality. The perceived importance of UGS is influenced by its adequacy. 
Table 3

Comparison of perception towards community quality attributes amongst the four residential communities.

\begin{tabular}{|c|c|c|c|c|c|c|c|c|c|c|c|c|c|}
\hline & \multirow{2}{*}{$\begin{array}{l}\text { Community } \\
\text { quality }\end{array}$} & \multirow{2}{*}{$\begin{array}{l}\text { Survey } \\
\text { question }\end{array}$} & \multicolumn{2}{|c|}{$\mathrm{OP}$} & \multicolumn{2}{|l|}{ OR } & \multicolumn{2}{|c|}{ SR } & \multicolumn{2}{|l|}{ NP } & \multirow{2}{*}{$\begin{array}{c}\text { F } \\
\text { statisti } \\
\text { C }\end{array}$} & \multicolumn{2}{|c|}{ Sig. } \\
\hline & & & $\begin{array}{c}\text { Mea } \\
\mathrm{n}\end{array}$ & $\begin{array}{l}\text { Weig } \\
\text { hted } \\
\%\end{array}$ & Mean & $\begin{array}{l}\text { Weigh } \\
\text { ted \% }\end{array}$ & Mean & $\begin{array}{l}\text { Weigh } \\
\text { ted \% }\end{array}$ & Mean & $\begin{array}{l}\text { Weigh } \\
\text { ted \% }\end{array}$ & & & \\
\hline C1 & Air quality & $\begin{array}{l}\text { "air quality is } \\
\text { good" }\end{array}$ & 2.44 & 77.2 & 2.18 & 69.0 & 3.16 & 100.0 & 2.67 & 84.5 & 49.85 & $\begin{array}{r}0.0 \\
00\end{array}$ & ** \\
\hline C2 & Noise & $\begin{array}{l}\text { "outdoor } \\
\text { environment is } \\
\text { quiet" }\end{array}$ & 2.46 & 77.8 & 2.11 & 66.8 & 3.16 & 100.0 & 2.46 & 77.8 & 52.38 & $\begin{array}{r}0.0 \\
00\end{array}$ & $* *$ \\
\hline C3 & $\begin{array}{l}\text { Landscape } \\
\text { quality }\end{array}$ & $\begin{array}{l}\text { "landscape is } \\
\text { beautiful" }\end{array}$ & 2.30 & 73.7 & 2.13 & 68.3 & 3.12 & 100.0 & 2.40 & 76.9 & 56.58 & $\begin{array}{r}0.0 \\
00\end{array}$ & $* *$ \\
\hline C4 & $\begin{array}{l}\text { Environmenta } \\
\text { l hygiene }\end{array}$ & $\begin{array}{l}\text { "environmental } \\
\text { hygiene } \\
\text { condition is } \\
\text { good" }\end{array}$ & 2.47 & 80.5 & 2.33 & 75.9 & 3.07 & 100.0 & 2.70 & 87.9 & 34.87 & $\begin{array}{r}0.0 \\
00\end{array}$ & $* *$ \\
\hline C5 & $\begin{array}{l}\text { Public } \\
\text { security }\end{array}$ & $\begin{array}{l}\text { "public security } \\
\text { is good" }\end{array}$ & 2.55 & 82.8 & 2.49 & 80.8 & 3.08 & 100.0 & 2.61 & 84.7 & 22.17 & $\begin{array}{r}0.0 \\
00\end{array}$ & ** \\
\hline C6 & $\begin{array}{l}\text { Accessibility } \\
\text { to } \\
\text { entertainment } \\
\text { facilities }\end{array}$ & $\begin{array}{l}\text { "supply of } \\
\text { large shopping } \\
\text { centers and } \\
\text { entertainment } \\
\text { facilities is } \\
\text { adequate" }\end{array}$ & 1.92 & 77.4 & 2.18 & 87.9 & 1.95 & 78.6 & 2.48 & 100.0 & 14.11 & $\begin{array}{r}0.0 \\
00\end{array}$ & ** \\
\hline C7 & $\begin{array}{l}\text { Neighborhood } \\
\text { relationship }\end{array}$ & $\begin{array}{l}\text { "good } \\
\text { relationship } \\
\text { with other } \\
\text { residents" }\end{array}$ & 2.86 & 100.0 & 2.58 & 90.2 & 2.73 & 95.5 & 2.65 & 92.7 & 4.56 & $\begin{array}{r}0.0 \\
04\end{array}$ & ** \\
\hline C8 & $\begin{array}{l}\text { Concern about } \\
\text { the } \\
\text { community }\end{array}$ & $\begin{array}{l}\text { "care about the } \\
\text { community’s } \\
\text { affairs" }\end{array}$ & 2.31 & 95.5 & 2.42 & 100.0 & 2.35 & 97.1 & 2.27 & 93.8 & 1.00 & $\begin{array}{r}0.3 \\
92\end{array}$ & \\
\hline C9 & Urban density & $\begin{array}{l}\text { "urban } \\
\text { environment is }\end{array}$ & 2.46 & 76.6 & 2.29 & 71.3 & 3.21 & 100.0 & 2.66 & 82.9 & 37.73 & $\begin{array}{r}0.0 \\
00\end{array}$ & $* *$ \\
\hline
\end{tabular}


crowded"

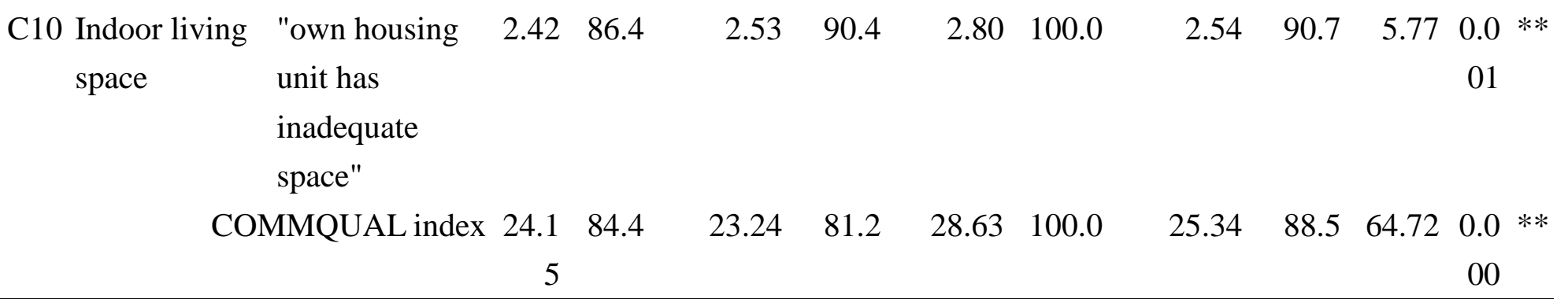

* Indicates significant at 0.05 level, and ** at 0.01 level.

Mean score:

For all except C9 and C10: 4=strongly agree, 3=agree, 2=slightly disagree, 1=strongly disagree.

For C9 and C10: 1=strongly agree, 2=agree, 3=slightly disagree, 4=strongly disagree.

COMMQUAL index: Aggregate measure for the above 10 items.

Table 4

Comparison of perceived importance of the functions of urban greenspaces amongst the four residential communities.

\begin{tabular}{|c|c|c|c|c|c|c|c|c|c|c|c|}
\hline \multirow[b]{2}{*}{ Function } & \multicolumn{2}{|c|}{ OP } & \multicolumn{2}{|l|}{ OR } & \multicolumn{2}{|c|}{ SR } & \multicolumn{2}{|c|}{ NP } & \multirow[b]{2}{*}{ atisti } & \multirow[b]{2}{*}{ Sig. } & \\
\hline & Mean & $\begin{array}{l}\text { Weigh } \\
\text { ted \% }\end{array}$ & Mean & $\begin{array}{c}\text { Weig } \\
\text { hted } \\
\%\end{array}$ & Mean & $\begin{array}{l}\text { Weigh } \\
\text { ted \% }\end{array}$ & Mean & $\begin{array}{l}\text { Weigh } \\
\text { ted \% }\end{array}$ & & & \\
\hline $\begin{array}{l}\text { F1 Encourage outdoor physical } \\
\text { exercises }\end{array}$ & 3.07 & 94.2 & 3.16 & 96.9 & 3.26 & 100.0 & 3.02 & 92.6 & 3.557 & 0.014 & $*$ \\
\hline $\begin{array}{l}\text { F2 Provide setting for social } \\
\text { interactions }\end{array}$ & 2.94 & 100.0 & 2.80 & 95.2 & 2.72 & 92.5 & 2.68 & 91.2 & 3.027 & 0.029 & $*$ \\
\hline $\begin{array}{l}\text { F3 Supply children’s } \\
\text { playgrounds }\end{array}$ & 3.25 & 95.0 & 3.34 & 97.7 & 3.42 & 100.0 & 3.14 & 91.8 & 3.537 & 0.015 & $*$ \\
\hline $\begin{array}{l}\text { F4 Furnish place for resting or } \\
\text { whiling away time }\end{array}$ & 3.08 & 98.1 & 3.11 & 99.0 & 3.14 & 100.0 & 3.06 & 97.5 & 0.270 & 0.847 & \\
\hline $\begin{array}{l}\text { F5 Insert buffer space between } \\
\text { buildings }\end{array}$ & 3.27 & 95.6 & 3.38 & 98.8 & 3.42 & 100.0 & 3.2 & 93.6 & 3.083 & 0.027 & $*$ \\
\hline F6 Enhance aesthetic quality & 3.46 & 99.1 & 3.36 & 96.3 & 3.49 & 100.0 & 3.44 & 98.6 & 1.220 & 0.302 & \\
\hline F7 Increase property value & 2.44 & 81.1 & 2.81 & 93.4 & 3.01 & 100.0 & 2.42 & 80.4 & 12.999 & 0.000 & $* *$ \\
\hline F8 Augment community image & 3.03 & 97.1 & 3.121 & 100.0 & 3.04 & 97.4 & 3.08 & 98.7 & 0.443 & 0.722 & \\
\hline F9 Lower urban air temperature & 3.32 & 97.6 & 3.35 & 98.5 & 3.4 & 100.0 & 3.26 & 95.9 & 0.876 & 0.453 & \\
\hline F10 Reduce air pollution & 3.46 & 95.8 & 3.39 & 93.9 & 3.61 & 100.0 & 3.5 & 97.0 & 2.939 & 0.033 & * \\
\hline F11 Abate noise & 2.91 & 95.7 & 2.99 & 98.4 & 3.04 & 100.0 & 2.98 & 98.0 & 0.540 & 0.656 & \\
\hline
\end{tabular}


F12 Offer shading

F13 Sequester carbon dioxide

F14 Prevent soil erosion

F15 Present wildlife habitat

F16 Promote health

F17 Allow more contact with nature

F18 Bestow symbol of identity

3.2496 .4

3.2396 .1

$3.36 \quad 100.0$

3.21

$\begin{array}{lll}95.5 & 1.360 & 0.255\end{array}$

$\begin{array}{llllll}3.32 & 95.4 & 3.20 & 92.0 & 3.48 & 100.0\end{array}$

$\begin{array}{llll}3.25 & 93.4 & 3.420 & 0.017\end{array}$ **

$\begin{array}{llllll}3.08 & 96.6 & 2.82 & 88.4 & 3.19 & 100.0\end{array}$

2.96

$92.8 \quad 4.544 \quad 0.004 * *$

$\begin{array}{llll}2.75 & 95.2 & 2.79 & 96.5\end{array}$

2.89100 .0

2.75

3.3596 .5

3.3997 .7

$3.47 \quad 100.0$

3.29

95.

$3.17 \quad 96.4$

3.2197 .6

3.29100 .0

$\begin{array}{llll}3.14 & 95.4 & 1.130 & 0.336\end{array}$

IMPORTANCE index

$2.51 \quad 97.7 \quad 2.57100 .0$

$2.43 \quad 94.6$

2.46

$95.7 \quad 0.550 \quad 0.650$

$\begin{array}{llllll}55.72 & 96.0 & 56.16 & 96.7 & 58.06 & 100.0\end{array}$

55.20

95

* Indicates significant at 0.05 level, and ** at 0.01 level.

Mean score: 4=very important, 3=important, 2=somewhat important, 1=not very important.

IMPORTANCE index: Aggregate measure for the above 18 items. 
Table 5

Comparison of perceived negative effects of urban greenspaces amongst the four residential communities.

\begin{tabular}{|c|c|c|c|c|c|c|c|c|c|c|}
\hline \multirow[b]{2}{*}{ Negative effect } & \multicolumn{2}{|c|}{$\mathrm{OP}$} & \multicolumn{2}{|c|}{ OR } & \multicolumn{2}{|c|}{ SR } & \multicolumn{2}{|c|}{ NP } & \multirow{2}{*}{$\begin{array}{c}\text { F } \\
\text { statist } \\
\text { ic }\end{array}$} & \multirow[b]{2}{*}{ Sig. } \\
\hline & Mean & $\begin{array}{l}\text { Weigh } \\
\text { ted \% }\end{array}$ & Mean & $\begin{array}{l}\text { Weigh } \\
\text { ted \% }\end{array}$ & Mean & $\begin{array}{l}\text { Weigh } \\
\text { ted \% }\end{array}$ & Mean & $\begin{array}{l}\text { Weight } \\
\text { ed } \%\end{array}$ & & \\
\hline $\begin{array}{l}\text { N1 Create dark and } \\
\text { hiding places }\end{array}$ & 2.33 & 98.7 & 2.34 & 99.2 & 2.14 & 90.7 & 2.36 & 100.0 & 2.488 & 0.060 \\
\hline $\begin{array}{l}\text { N2 Induce gang } \\
\text { problems }\end{array}$ & 2.20 & 95.7 & 2.30 & 100.0 & 1.91 & 83.0 & 2.17 & 94.3 & 5.685 & $0.001 * *$ \\
\hline N3 Occupy urban spaces & 2.11 & 97.7 & 2.16 & 100.0 & 1.81 & 83.8 & 2.05 & 94.9 & 5.477 & $0.001 * *$ \\
\hline N4 Block light & 2.32 & 99.6 & 2.33 & 100.0 & 2.02 & 86.7 & 2.16 & 92.7 & 4.559 & $0.004 * *$ \\
\hline $\begin{array}{l}\text { N5 Generate messy } \\
\text { organic litter }\end{array}$ & 2.37 & 100.0 & 2.30 & 97.0 & 2.10 & 88.6 & 2.15 & 90.7 & 3.512 & $0.015 *$ \\
\hline NEGEFFECT index & 11.27 & 98.6 & 11.43 & 100.0 & 9.98 & 87.3 & 10.87 & 95.1 & 7.397 & $0.000 * *$ \\
\hline
\end{tabular}

* Indicates significant at 0.05 level, and ** at 0.01 level.

Mean score: 1=strongly disagree, $2=$ slightly disagree, 3=agree, $4=$ strongly agree.

NEGEFFECT index: Aggregate measure for the above 5 items. 
Table 6

Comparison of the frequency and companion of visits to urban greenspaces amongst the four

residential communities.

\begin{tabular}{|c|c|c|c|c|c|c|c|}
\hline \multirow{2}{*}{$\begin{array}{l}\text { Visit frequency or visit } \\
\text { companion }\end{array}$} & \multicolumn{4}{|c|}{$\begin{array}{l}\text { Percent of respondents } \\
\text { (within each community) }\end{array}$} & \multirow{2}{*}{$\begin{array}{c}\text { Cramer's } \\
\text { V }\end{array}$} & \multirow[t]{2}{*}{$\begin{array}{l}\text { Approx. } \\
\text { Sig. }\end{array}$} & \multirow[t]{2}{*}{$\mathrm{N}$} \\
\hline & OP & OR & SR & NP & & & \\
\hline \multicolumn{8}{|l|}{ Visit frequency } \\
\hline $\begin{array}{l}\text { Less than once per } \\
\text { month }\end{array}$ & 17.2 & 9.6 & 11.6 & 20.6 & 0.107 & 0.155 & 495 \\
\hline Monthly & 11.2 & 12.3 & 12.4 & 15.9 & & & \\
\hline Weekly & 26.1 & 21.9 & 24.0 & 23.8 & & & \\
\hline 2 - 6 times per week & 18.7 & 32.5 & 30.6 & 20.6 & & & \\
\hline At least once per day & 26.9 & 23.7 & 21.5 & 19.0 & & & \\
\hline \multicolumn{8}{|l|}{ Visit companion } \\
\hline Children & 20.6 & 35.7 & 24.4 & 17.7 & 0.193 & 0.000 & 486 \\
\hline Other family members & 23.7 & 28.6 & 46.2 & 20.2 & & & \\
\hline Neighbors or friends & 23.7 & 8.9 & 7.6 & 25.8 & & & \\
\hline Pets & 1.5 & 1.8 & 1.7 & 5.6 & & & \\
\hline Alone & 30.5 & 25.0 & 20.2 & 30.6 & & & \\
\hline
\end{tabular}


Table 7

Comparison of the stated purpose of visiting urban greenspaces amongst the four residential communities.

\begin{tabular}{|c|c|c|c|c|c|c|c|c|c|c|}
\hline \multirow{2}{*}{ Visit purpose } & \multicolumn{2}{|c|}{ OP } & \multicolumn{2}{|l|}{ OR } & \multicolumn{2}{|c|}{ SR } & \multicolumn{2}{|c|}{ NP } & \multirow{2}{*}{$\begin{array}{c}\mathrm{F} \\
\text { statisti } \\
\mathrm{C}\end{array}$} & \\
\hline & $\begin{array}{c}\text { Mea } \\
\mathrm{n}\end{array}$ & $\begin{array}{l}\text { Weigh } \\
\text { ted } \%\end{array}$ & Mean & $\begin{array}{c}\text { Weig } \\
\text { hted } \\
\%\end{array}$ & Mean & $\begin{array}{l}\text { Weigh } \\
\text { ted \% }\end{array}$ & Mean & $\begin{array}{l}\text { Weigh } \\
\text { ted \% }\end{array}$ & & \\
\hline H1 While away time & 1.80 & 100.0 & 1.63 & 90.6 & 1.64 & 91.1 & 1.75 & 97.2 & 1.5750 .195 & \\
\hline H2 Breathe clean air & 2.21 & 93.2 & 2.17 & 91.6 & 2.37 & 100.0 & 2.08 & 87.8 & 3.2900 .021 & * \\
\hline H3 Exercise or stroll & 2.31 & 100.0 & 2.19 & 94.8 & 2.27 & 98.3 & 2.19 & 94.8 & 0.8490 .467 & \\
\hline $\begin{array}{l}\text { Enjoy tranquil ambience } \\
\text { and relax }\end{array}$ & 2.10 & 94.2 & 2.04 & 91.5 & 2.23 & 100.0 & 2.02 & 90.6 & 1.9760 .117 & \\
\hline $\begin{array}{l}\text { H5 Enjoy the natural } \\
\text { landscape }\end{array}$ & 1.87 & 88.2 & 1.86 & 87.7 & 2.12 & 100.0 & 1.86 & 87.7 & 3.4780 .016 & * \\
\hline H6 Chat or gather with friends & 1.92 & 100.0 & 1.54 & 80.2 & 1.60 & 83.3 & 1.78 & 92.7 & 6.8300 .000 & ** \\
\hline $\begin{array}{l}\text { H7 } \begin{array}{l}\text { Take children to } \\
\text { playground }\end{array}\end{array}$ & 1.63 & 86.2 & 1.89 & 100 & 1.84 & 97.4 & 1.54 & 81.5 & 4.9030 .002 & $* *$ \\
\hline $\begin{array}{l}\text { Enjoy the cool } \\
\text { environment }\end{array}$ & 1.70 & 100.0 & 1.60 & 94.1 & 1.64 & 96.5 & 1.51 & 88.8 & 1.6520 .177 & \\
\hline
\end{tabular}

* Indicates significant at 0.05 level, and ** at 0.01 level.

Mean score: 3=often, 2=sometimes, 1=seldom. 
Table 8

Comparison of the site problems of urban greenspaces situated near residences amongst the four the residential communities.

\begin{tabular}{|c|c|c|c|c|c|c|c|c|c|c|c|}
\hline \multirow[b]{2}{*}{ Site problem } & \multicolumn{2}{|c|}{ OP } & \multicolumn{2}{|c|}{ OR } & \multicolumn{2}{|c|}{ SR } & \multicolumn{2}{|c|}{ NP } & 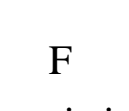 & \multirow[b]{2}{*}{ Sig. } & \\
\hline & Mean & $\begin{array}{c}\text { Weig } \\
\text { hted } \\
\%\end{array}$ & Mean & $\begin{array}{l}\text { Weigh } \\
\text { ted \% }\end{array}$ & Mean & $\begin{array}{l}\text { Weigh } \\
\text { ted \% }\end{array}$ & Mean & $\begin{array}{l}\text { Weigh } \\
\text { ted \% }\end{array}$ & $\begin{array}{l}\text { statisti } \\
\text { C }\end{array}$ & & \\
\hline $\begin{array}{l}\text { P1 Poor landscape } \\
\text { quality }\end{array}$ & 2.41 & 100.0 & 2.39 & 99.2 & 2.03 & 84.2 & 2.41 & 100.0 & 10.467 & 0.000 & $* *$ \\
\hline P2 Too far from home & 2.04 & 90.7 & 2.19 & 97.3 & 2.06 & 91.6 & 2.25 & 100.0 & 3.792 & 0.010 & $* *$ \\
\hline P3 Site area too small & 2.42 & 95.3 & 2.54 & 100.0 & 2.14 & 84.3 & 2.33 & 91.7 & 7.279 & 0.000 & $* *$ \\
\hline $\begin{array}{l}\text { P4 Inadequate seats or } \\
\text { pavilions }\end{array}$ & 2.43 & 92.7 & 2.62 & 100.0 & 2.34 & 89.3 & 2.59 & 98.9 & 4.533 & 0.004 & ** \\
\hline $\begin{array}{l}\text { P5 Poor hygiene } \\
\text { condition }\end{array}$ & 2.29 & 100.0 & 2.23 & 97.4 & 1.85 & 80.8 & 2.16 & 94.3 & 13.122 & 0.000 & $* *$ \\
\hline P6 Too many people & 2.47 & 96.9 & 2.55 & 100.0 & 1.96 & 76.9 & 2.47 & 96.9 & 24.783 & 0.000 & $* *$ \\
\hline $\begin{array}{l}\text { P7 Inadequate sports } \\
\text { facilities }\end{array}$ & 2.71 & 93.1 & 2.91 & 100.0 & 2.75 & 94.5 & 2.80 & 96.2 & 1.870 & 0.134 & \\
\hline $\begin{array}{l}\text { P8 Inadequate } \\
\text { greenery }\end{array}$ & 2.52 & 97.7 & 2.58 & 100.0 & 2.11 & 81.8 & 2.38 & 92.2 & 13.116 & 0.000 & $* *$ \\
\hline SITEPROB index & 19.28 & 96.3 & 20.03 & 100.0 & 17.27 & 86.2 & 19.47 & 97.2 & 16.871 & 0.000 & $* *$ \\
\hline
\end{tabular}

* Indicates significant at 0.05 level, and ** at 0.01 level.

Mean score: 1=strongly disagree, 2=slightly disagree, 3=agree, 4=strongly agree.

SITEPROB index: total score of all the 8 items. 
Table 9

Comparison of the preference for park design features amongst the four residential communities.

\begin{tabular}{|c|c|c|c|c|c|c|c|}
\hline \multirow[b]{2}{*}{ Park design feature } & \multicolumn{4}{|c|}{$\begin{array}{l}\text { Percent of respondents } \\
\text { (within each community) }\end{array}$} & \multirow[b]{2}{*}{$\begin{array}{r}\text { Cramer's } \\
\mathrm{V}\end{array}$} & \multirow[b]{2}{*}{$\begin{array}{r}\text { Approx. } \\
\text { Sig. }\end{array}$} & \multirow[b]{2}{*}{$\mathrm{N}$} \\
\hline & $\mathrm{OP}$ & OR & SR & NP & & & \\
\hline \multicolumn{8}{|l|}{ Park facility } \\
\hline More trees & 56.4 & 57.9 & 60.0 & 56.3 & 1.512 & 0.959 & 493 \\
\hline More seats & 14.3 & 15.8 & 11.7 & 12.7 & & & \\
\hline More sports facilities & 29.3 & 26.3 & 28.3 & 31.0 & & & \\
\hline \multicolumn{8}{|l|}{ Seat arrangement } \\
\hline Clustered & 17.2 & 7.9 & 4.1 & 14.3 & 0.155 & 0.000 & 495 \\
\hline Dispersed & 50.7 & 73.7 & 62.0 & 55.6 & & & \\
\hline No preference & 32.1 & 18.4 & 33.9 & 30.2 & & & \\
\hline \multicolumn{8}{|l|}{ Park size } \\
\hline One large park & 57.5 & 71.9 & 46.3 & 46.8 & 0.151 & 0.001 & 495 \\
\hline $\begin{array}{l}\text { Several small parks } \\
\text { (with similar total area) }\end{array}$ & 23.1 & 15.8 & 31.4 & 25.4 & & & \\
\hline No preference & 19.4 & 12.3 & 22.3 & 27.8 & & & \\
\hline
\end{tabular}


Table 10

Summary of the relative strength of the perception, habit and preference concerning urban greenspaces in the four residential communities.

\begin{tabular}{|c|c|c|c|c|}
\hline Attribute & $\mathrm{OP}$ & OR & SR & NP \\
\hline $\begin{array}{l}\text { Perceived } \\
\text { importance }\end{array}$ & Moderate & Moderate & Higher & Lower \\
\hline $\begin{array}{l}\text { Perceived negative } \\
\text { effect }\end{array}$ & More sensitive & More sensitive & Less sensitive & Moderate \\
\hline Visit frequency & Less frequent & More frequent & More frequent & Less frequent \\
\hline Visit companion & $\begin{array}{l}\text { More with } \\
\text { neighbors/ } \\
\text { friends }\end{array}$ & $\begin{array}{l}\text { More with } \\
\text { family } \\
\text { members }\end{array}$ & $\begin{array}{l}\text { More with family } \\
\text { members }\end{array}$ & $\begin{array}{l}\text { More with } \\
\text { neighbors/ } \\
\text { friends }\end{array}$ \\
\hline Visit purpose & $\begin{array}{l}\text { More } \\
\text { socially-oriented }\end{array}$ & $\begin{array}{l}\text { More for } \\
\text { children }\end{array}$ & $\begin{array}{c}\text { More for } \\
\text { environmental / } \\
\text { aesthetic enjoyment }\end{array}$ & Mixed \\
\hline Site problem & Less satisfied & Less satisfied & More satisfied & Less satisfied \\
\hline Park facility & \multicolumn{4}{|c|}{$\begin{array}{l}\text { Consistently strong preference for more trees than seats or sports } \\
\qquad \text { facilities }\end{array}$} \\
\hline Seat arrangement & $\begin{array}{l}\text { Less for } \\
\text { dispersed }\end{array}$ & $\begin{array}{l}\text { More for } \\
\text { dispersed }\end{array}$ & More for dispersed & $\begin{array}{l}\text { Less for } \\
\text { dispersed }\end{array}$ \\
\hline Park size & $\begin{array}{l}\text { More for a large } \\
\text { one }\end{array}$ & $\begin{array}{l}\text { More for a } \\
\text { large one }\end{array}$ & $\begin{array}{l}\text { Less for a } \\
\text { large one }\end{array}$ & $\begin{array}{l}\text { Less for a } \\
\text { large one }\end{array}$ \\
\hline
\end{tabular}


Table 11

Regression models for the perception on the importance and negative effects of urban greenspaces.

Model 1

Model 2

(dependent variable: IMPORTANCE)

(dependent variable: NEGEFFECT)

\begin{tabular}{|c|c|c|c|c|c|c|c|c|}
\hline & Coefficient & Std. Error & $\mathrm{t}$ & Sig. & Coefficient & Std. Error & $\mathrm{t}$ & Sig. \\
\hline (Constant) & & 4.478 & 5.154 & 0.000 & & 1.676 & 7.378 & 0.000 \\
\hline \multicolumn{9}{|l|}{ Socioeconomic variables } \\
\hline Years of Residence & 0.022 & 0.368 & 0.480 & 0.632 & -0.025 & 0.138 & -0.522 & 0.602 \\
\hline Children & 0.008 & 0.708 & 0.185 & 0.853 & -0.061 & 0.265 & -1.301 & 0.194 \\
\hline Education & 0.134 & 0.605 & 2.601 & $0.010 * *$ & -0.123 & 0.227 & -2.265 & $0.024 *$ \\
\hline Age & 0.066 & 0.568 & 1.168 & 0.243 & 0.086 & 0.213 & 1.451 & 0.147 \\
\hline Retired & -0.116 & 1.210 & -1.989 & $0.047 *$ & -0.020 & 0.452 & -0.332 & 0.740 \\
\hline Income & 0.055 & 0.333 & 1.066 & 0.287 & -0.098 & 0.125 & -1.826 & 0.069 \\
\hline Gender & -0.134 & 0.671 & -2.982 & $0.003 * *$ & -0.042 & 0.251 & -0.892 & 0.373 \\
\hline VISITFREQ & 0.160 & 0.264 & 3.415 & $0.001 * *$ & -0.001 & 0.099 & -0.024 & 0.981 \\
\hline SITEPROB & 0.213 & 0.116 & 4.217 & $0.000 * *$ & 0.067 & 0.043 & 1.263 & 0.207 \\
\hline \multicolumn{9}{|c|}{ Community quality attributes } \\
\hline $\begin{array}{l}\text { Urban Morphology } \\
\text { Factor }\end{array}$ & 0.236 & 0.127 & 4.507 & $0.000 * *$ & -0.136 & 0.047 & -2.482 & $0.013 *$ \\
\hline $\begin{array}{l}\text { Community Membership } \\
\text { Factor }\end{array}$ & 0.179 & 0.323 & 3.900 & $0.000 * *$ & 0.054 & 0.121 & 1.131 & 0.259 \\
\hline Indoor Living Space & -0.016 & 0.440 & -0.363 & 0.716 & -0.003 & 0.165 & -0.061 & 0.951 \\
\hline $\begin{array}{l}\text { Accessibility to } \\
\text { Entertainment Facilities }\end{array}$ & 0.053 & 0.411 & 1.193 & 0.234 & 0.025 & 0.154 & 0.545 & 0.586 \\
\hline Adj. $R^{2}$ & & & & 0.15 & & & & 0.07 \\
\hline F statistic & & & & 7.263 & & & & 3.685 \\
\hline Std. Error & & & & 6.871 & & & & 2.574 \\
\hline Sig. & & & & 0.000 & & & & 0.000 \\
\hline Total df & & & & 453 & & & & 454 \\
\hline
\end{tabular}

* Indicates significant at 0.05 level, and ** at 0.01 level

Note: IMPORTANCE and NEGEFFECT: aggregate measures for the perception about the importance and negative effects of urban greenspaces

VISITFREQ: frequency of visit to urban greenspaces

Urban Morphology Factor (C1-C5 and C9), Community Membership (C7-C8), Indoor Living Space (C10), and Accessibility to Entertainment Facilities (C6): measures for perceived quality 


\section{Table 12}

Chi-square contingency test results of the cross-tabulation between visit frequency versus site problems of urban greenspaces near residences and community quality attributes.

\begin{tabular}{lrlllc}
\hline Site problem & Cramer's & Sig. & Community quality & Cramer's & Sig. \\
& $\mathrm{V}$ & & & $\mathrm{V}$ & 0.070 \\
\hline P1. Poor landscape quality & 0.093 & 0.393 & C1. Air quality & 0.832 \\
P2. Too far from home & 0.124 & $0.030 *$ & C2. Noise & 0.084 & 0.585 \\
P3. Site area too small & 0.082 & 0.624 & C3. Landscape quality & 0.125 & $0.026 *$ \\
P4. Inadequate seats or pavilions & 0.061 & 0.945 & C4. Environmental hygiene & 0.111 & 0.105 \\
P5. Poor hygiene condition & 0.083 & 0.604 & C5. Public security & 0.120 & $0.047 *$ \\
P6. Too many people & 0.056 & 0.970 & C6. Accessibility to entertainment facilities & 0.117 & 0.064 \\
P7. Inadequate sports facilities & 0.094 & 0.375 & C7. Neighborhood relationship & 0.123 & $0.034 *$ \\
P8. Inadequate greenery & 0.054 & 0.977 & C8. Concern about the community & 0.160 & $0.000 * *$ \\
& & & C9. Urban density & 0.099 & 0.272 \\
& & & C10. Indoor living space & 0.086 & 0.532 \\
\hline
\end{tabular}

* Indicates significant at 0.05 level, and ** at 0.01 level 